Asia Proceedings of Social Sciences

(APSS)

www.readersinsight.net/APSS

\title{
Analysis of Consumer Satisfaction and Loyalty for the Implementation of Minimarket Information Systems Based Gender
}

\author{
Yuhelmi* \\ Departement of Management, University of Bung Hatta \\ Indonesia \\ Surya Dharma \\ Departement of Management, University of Bung Hatta \\ Indonesia

\section{Listiana Sri Mulatsih} \\ Departement of Management, University of Bung Hatta \\ Indonesia
}

*Corrosponding author's Email: yuhelmis@yahoo.co.id

Peer-review under responsibility of $4^{\text {th }}$ Asia International Conference 2018 editorial board (http://www.utm.my/asia/our-team/) (C) 2018 Published by Readers Insight Publisher, lat 306 Savoy Residencia, Block 3 F11/1,44000 Islamabad. Pakistan, info@ readersinsight.net This is an open access article under the CC BY-NC-ND license(http://creativecommons.org/licenses/by-nc-nd/4.0/). 


\section{Research High Iight s}

This study proposed two hypotheses and the results indicated that based on gender there are differences in satisfaction and consumer loyalty in the implementation of information systems at the minimarket. Male consumers tend to have high levels of satisfaction and loyalty compared to female consumers. The information provided by the minimarket both manually and based on the Point of sale (POS) application has been quite satisfying for men in shopping. Men in shopping prefer practical and fast without much consideration, while women need more detailed information to make buying decisions.

\section{Research Objectives}

This study aims to investigate differences in satisfaction and consumer loyalty of minimarkets by gender in the framework of implementing information systems. The information system that is applied will provide several impacts that can satisfy or not satisfy consumers. The ease of obtaining price information and stock availability will help consumers make purchasing decisions. If consumers find it easy to get the information, it is also easy to make decisions that ultimately consumers feel satisfied. Male consumers will be faster satisfied with the availability of information, but women will be more satisfied if the ease of obtaining more complete and detailed information. The number of cashiers who served consumers in making payments using the computer-based POS information technology system and the dexterity of the cashier in providing services will affect customer satisfaction. Consumers face a long queue due to the number of cashiers who are few and less dexterous, will become dissatisfied and disloyal. The POS application system produces a shopping receipt that can help consumers assess the accuracy of shopping value. The availability of alternative payment methods helps consumers make payments. Not all consumers like to make payments in cash, but alternative methods of payment using a credit / debit card will help consumers. 


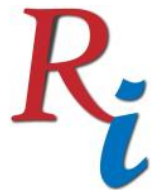

Asia Proceedings of Social Sciences

(APSS)

www.readersinsight.net/APSS

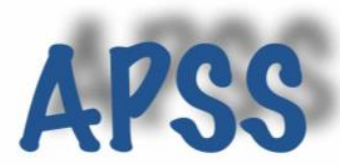

\section{Methodology}

The population of this research is minimarket consumers in the city of Padang. The sampling technique was used accidental sampling, ie consumers who could be found shopping at the minimarket with a total sample of 243 respondents who filled out the questionnaire in full. The type of data used is primary data collected by distributing questionnaires. The measurement scale used the 5 point Linkert scale ranging from very dissatisfied to very satisfied for satisfaction measurements, and very disloyal to very loyal for measuring loyalty. The analytical method used to test the differences in satisfaction and consumer loyalty by gender is used non parametric test using the Kruskal Wallis test because the data is not normally distributed.

\section{Results}

Based on the profile of respondents it was found that $72 \%$ of respondents were female and only $28 \%$ were male. These results indicate that the most frequent and many go shopping is women of productive age, aged 18-35 years. Motiv consumers choose minimarkets as the dominant shopping place close to their homes, have a large parking area and the types of goods available are complete. The results of testing hypothesis 1 found that there was a difference in customer satisfaction based on gender, ( $p$ value 0.006 was smaller than $\alpha 0.05$ ), where men were higher in satisfaction than women. Testing hypothesis 2 found that there were differences in consumer loyalty by gender ( $p$ value 0.034 smaller than $\alpha 0.05$ ), where men were more loyal than women.

\section{Findings}

Based on the results of testing hypothesis 1 found differences in consumer satisfaction between men and women. These results indicate that gender has different satisfaction in obtaining information system services. Women will be satisfied if the information received is more detailed, the queue does not require a long time, the information produced is accurate, the cashier is more agile. Hypothesis 2 found that there was a difference in consumer loyalty by gender. Men will be more loyal than women because there are not too many 


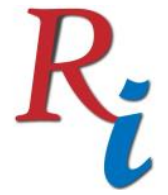

\section{Asia Proceedings of Social Sciences \\ (APSS) \\ www.readersinsight.net/APSS}

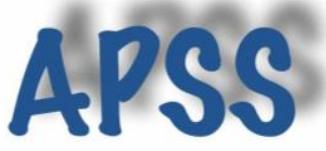

considerations in choosing a minimarket as a place to shop. It is different with women, where women in shopping are less rational.

\section{References}

Bailey, J. and Pearson, S. 1983. Development of a tool for measurement and analyzing computer user satisfaction. Management Science, 29(5), pp. 530 -575

Bloemer, J. (1998). On the relationship between store image , store satisfaction, 32(5), 499513.

Dineshkumar, U., \& Vikkraman, P. (2012). Customer s ' Satisfaction towards Organized Retail Outlets in Erode City, 3(4), 34-40.

Ghosh, Piyali., \& Tripathi, V. (2010). Customer expectations of store attributes : A study of organized retail outlets in India, 9(November 2009), 75-87. https://doi.org/10.1057/rlp.2009.27

Gronholdt, L., Martensen, A., \& Kristensen, K. (2010). The relationship between customer satisfaction and loyalty : Cross-industry differences, (September 2013), 37-41. https://doi.org/10.1080/09544120050007823

Janda, S., Trocchia, P. J., \& Gwinner, K. P. (2001). Consumer perceptions of Internet retail service quality. https://doi.org/10.1108/09564230210447913

Kotler, Philip \& Keller, Kevin L. (2012). Marketing Management., 13 ${ }^{\text {th }}$. New Jersey. Pearson Prentice Hall Inc

Livari,Juhani. 2005. An Empirical Test of the DeLone and McLean Model of Information System Success. Database for Advances in Information Systems. Spring. 36,2.pg.8.

Miguel, I. G., Mclaughlin, E. W., \& Wittink, D. R. (2004). Customer satisfaction and retail sales performance: an empirical investigation \&, 80, 265-278. https://doi.org/10.1016/j.jretai.2004.10.003

Orth, U. R., \& Green, M. T. (2009). Journal of Retailing and Consumer Services Consumer loyalty to family versus non-family business: The roles of store image, trust and satisfaction, 16, 248-259. https://doi.org/10.1016/j.jretconser.2008.12.002

Rai, A., Lang, S.S. and Welker, R.B. 2002. Assessing the Validity of IS Success Models: An Empirical Test and Theoretical Analysis, Information System Research. Vol.13, No.1. pp. 29-34.

Sirohi, N., \& Wittink, D. R. (1998). A Model of Consumer Perceptions and Store Loyalty Intentions for a Supermarket Retailer, 74(2), 223-245.

Utami, C. W. (2010). Manajemen ritel (2nd ed.). Jakarta: Salemba Empat.

Winarno, Wing Wahyu., (2017). "Sistem Informasi Manajemen” Edisi 3., Yogyakarta., UPP STIM YKPN 